\title{
Granular cell myoblastoma of the biliary tree
}

\author{
Ann Savage \\ M.B., B.S. \\ P. DevitT \\ M.B., Ch.B. \\ Departments of Pathology and Surgery, Southmead Hospital, Westbury-on-Trym, Bristol
}

\begin{abstract}
Summary
A granular cell myoblastoma of the common bile duct is described which caused episodes of jaundice in a young woman. Histological examination demonstrated a close association of the tumour with nerve fibres, tending to support the theory of origin from Schwann cells. The lesion is benign and after excision carries an excellent prognosis.
\end{abstract}

\section{Introduction}

Granular cell myoblastoma is an uncommon benign lesion of uncertain histogenesis. It was first described in 1926 by Abrikossof who considered that the cells composing the tumour resembled embryonal skeletal muscle. This is no longer generally accepted but the name is still widely used. The lesion occurs most frequently in the oral cavity and skin, but has been described in a wide variety of other situations (Paskin, Hull and Cookson, 1972). Its occurrence in the biliary tree is rare and although fifteen previous cases have been described, there is none in the British literature.

\section{Case history}

A female Caucasian was first seen in 1959 at the age of 16 years with jaundice. This was thought to be infective in origin, though the course of the illness was noted to be rather prolonged. Liver function tests at that time were: alkaline phosphatase 89 i.u./l (normal 20-110 i.u./l), SGPT (alanine aminotransferase) 190 i.u./l (normal range less than 35 i.u./l) and bilirubin $22 \mu \mathrm{mol} / \mathrm{l}$ (normal range less than $20 \mu \mathrm{mol} / \mathrm{l})$.

Ten years later she again became jaundiced, giving a 3-day history of general malaise, pruritus, abdominal pain and dark urine. Liver function tests were: alkaline phosphatase 138 i.u./l, SGPT 104 i.u./l and bilirubin $40 \mu \mathrm{mol} / \mathrm{l}$. An Australia antigen test was negative. Again the course of the illness was prolonged, an obstructive aetiology considered, but her enzyme levels then started to return to normal and so this was considered unlikely. A cholecystogram, performed during this episode, failed to reveal a functioning gall bladder but this was thought to be consistent with her persistent jaundice.
In April 1975, at the age of 30 years she again became jaundiced, this being associated with nausea, flatulence and heartburn. She had generalized pruritus and noted her urine had turned dark. Liver function tests showed: alkaline phosphatase 338 i.u./l, SGPT 863 i.u./l and bilirubin $44 \mu \mathrm{mol} / 1$. Again an oral cholecystogram failed to opacify the gall bladder. However i.v. cholangiogram sug gested a stricture of the common hepatic duct with proximal dilatation.

At laparotomy in July 1975 a dense fibrous biliary stricture was found high in the porta hepatis. Operative transhepatic cholangiography demonstrated gross dilatation of the right and left hepatie ducts but failed to outline the distal biliary tree. The mass of fibrous tissue had also occluded the cystic duct with consequent gall bladder distension Cholecystectomy was performed, the fibrous stric $=$ ture excised and cholehepatico-jejunostomy carried out with a Roux loop. A wedge biopsy of liver was also taken.

The patient made a satisfactory postoperative recovery and her liver function tests rapidly returned to normal.

\section{Pathological findings}

The gall bladder measured $80 \times 40 \times 30 \mathrm{~mm}$ and had a thickened wall up to $5 \mathrm{~mm}$ but contained no stones. Histologically there was mild chronic cholecystitis but no evidence of neoplasm. Sections of the wedge biopsy of liver showed only slight portal inflammation without cholestasis.

The material removed from around the common bile duct consisted of an irregular mass of tissue $20 \times$ $25 \times 30 \mathrm{~mm}$., with $30 \mathrm{~mm}$ of opened bile duct attached to one side. Sections showed that the common bile duct was eccentrically surrounded by fibrous tissue which was diffusely infiltrated by large polygonal or elongated cells with small dark nuclei and abundant granular eosinophilic cytoplasm (Figs. 1 and 2). The granules were markedly positive with the periodic acid-Schiff reaction. Numerous nerve bundles of varying size were present in the excised tissue; the granular cells closely encircled them and in some cases could be seen within the bundle 


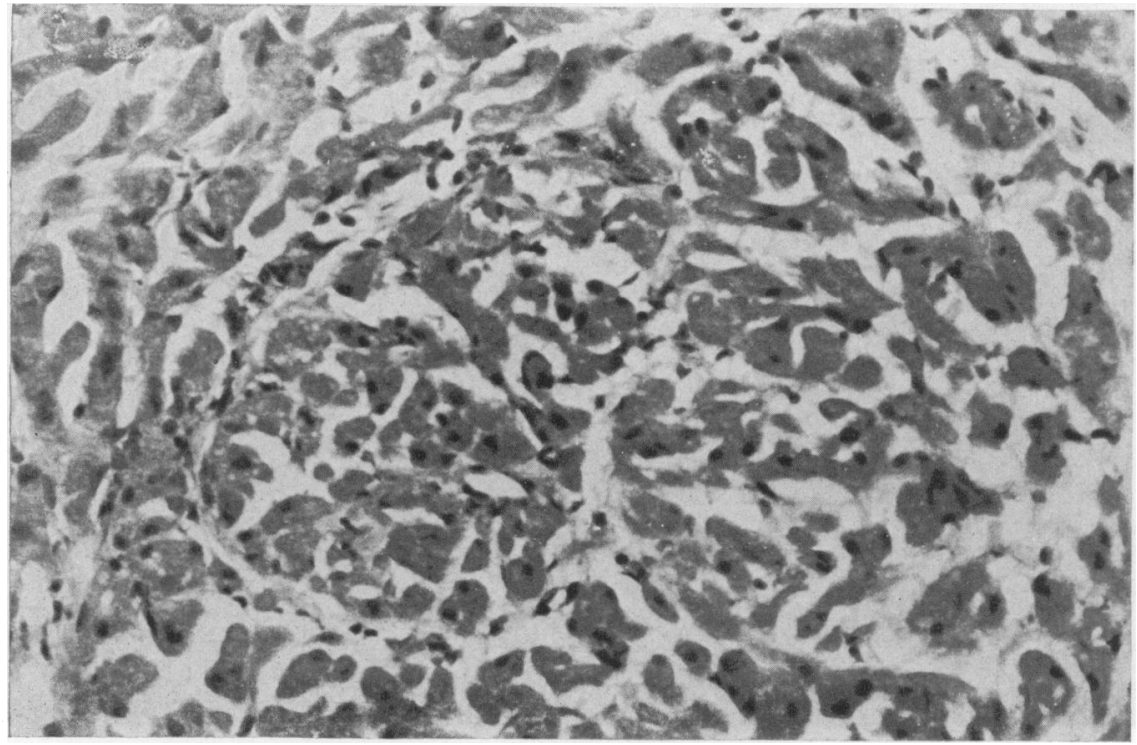

Fig. 1. The tumour is composed of large cells with small dark nuclei (H. and E. $\times 438$ ).

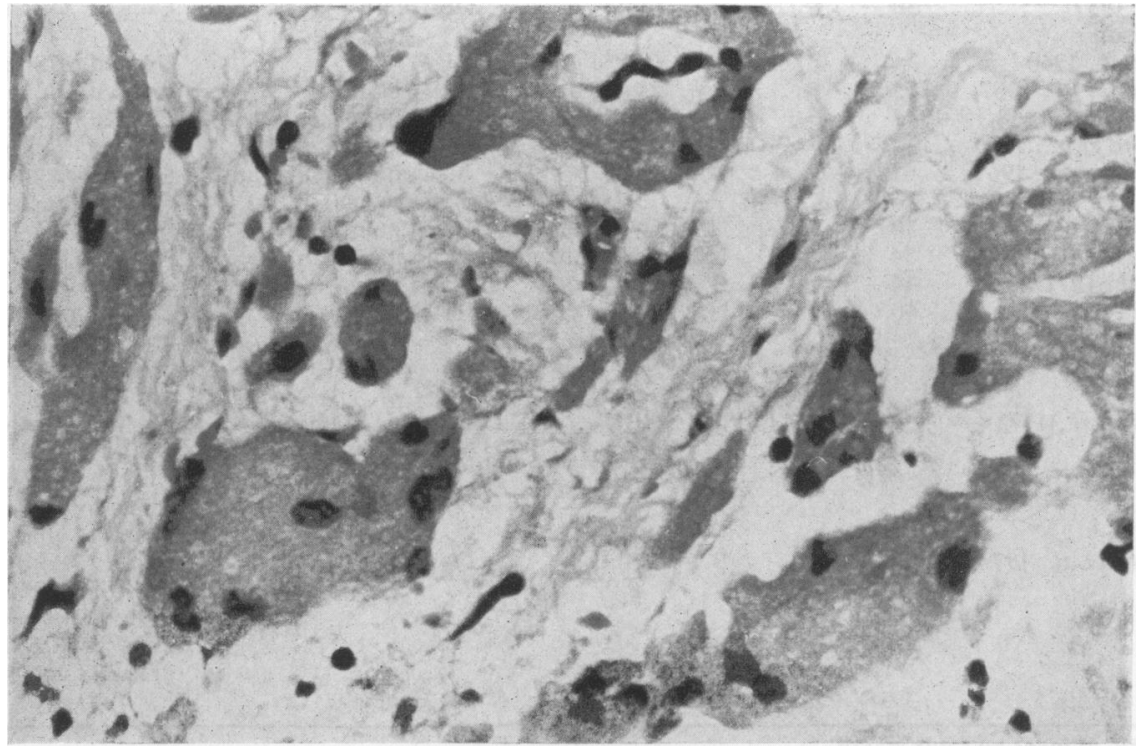

Fig. 2. High power view of tumour showing granular cytoplasm $(H$. and $E . \times 875)$. 


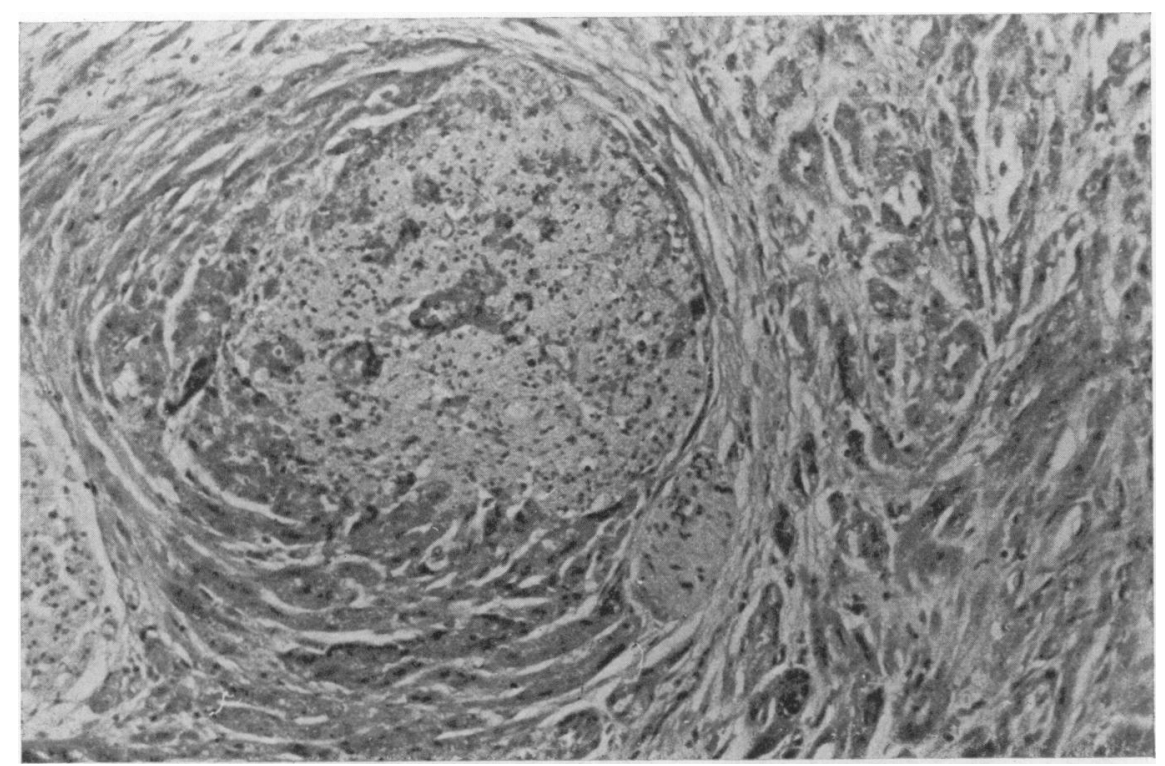

FIG. 3. Tumour cells are within and closely surrounding a nerve bundle $(H$. and $E . \times 263)$.

TABLE 1. Summary of previously reported cases

\begin{tabular}{|c|c|c|c|c|c|c|c|}
\hline Case & Author & $\begin{array}{c}\text { Age } \\
\text { (years) }\end{array}$ & Sex & Race * & Situation $\dagger$ & Symptoms $\ddagger$ & Treatment and Comment \\
\hline 1 & Coggins 1952 & 25 & $\mathbf{F}$ & B & CBD & $\begin{array}{l}\text { Liver failure, } \\
\text { Congestive cardiac } \\
\text { failure }\end{array}$ & Diagnosed at post-mortem $\frac{\vec{Q}}{\partial}$ \\
\hline 2 & $\begin{array}{l}\text { Fialho } 1952 \\
\text { and Hilarco, }\end{array}$ & 21 & $\mathbf{F}$ & B & Cystic duct & RUQ pain & Excised. Well at follow-up \\
\hline 3 & $\begin{array}{l}\text { Duncan } 1957 \\
\text { and Wilson }\end{array}$ & 30 & F & B & CBD & Obstructive jaundice & Excised. Discharged well \\
\hline 4 & Serpe et al., 1960 & 34 & $\mathrm{~F}$ & B & Cystic duct & RUQ pain & Excised. Well at follow-up \\
\hline 5 & Goldman et al., 1967 & 15 & $\mathbf{F}$ & B & Cystic duct & RUQ pain & Excised \\
\hline 6 & Mackay et al., 1968 & 45 & $\mathrm{~F}$ & NS & Cystic duct & RUQ pain & Excised. Well 9 months later \\
\hline 7 & Whitmore et al., 1969 & 37 & $\mathbf{F}$ & B & CBD & Obstructive jaundice & Excised. Discharged well \\
\hline 8 & Whitmore et al., 1969 & 61 & $\mathbf{F}$ & $\mathbf{B}$ & CBD & $\begin{array}{l}\text { Incidental finding at } \\
\text { post-mortem }\end{array}$ & $\begin{array}{l}\text { Chronic alcoholic with } \\
\text { chronic lung disease }\end{array}$ \\
\hline 9 & Christensen 1970 & 34 & $\mathbf{F}$ & NS & Cystic duct & RUQ pain & NS \\
\hline 10 & Christensen 1970 & 34 & $\mathbf{F}$ & NS & Cystic duct & Epigastric pain & NS \\
\hline 11 & Abt et al., 1971 & 44 & $\mathbf{F}$ & B & Cystic duct & RUQ pain & Excised \\
\hline 12 & Li Volsi et al., 1973 & 40 & $\mathbf{F}$ & NS & Cystic duct & RUQ pain & $\begin{array}{l}\text { Died of myocardial in- } \\
\text { farction } 4 \text { years after } \\
\text { excision. No evidence of } \\
\text { tumours }\end{array}$ \\
\hline 13 & Li Volsi et al., 1973 & 30 & $\mathbf{F}$ & NS & CBD & $\begin{array}{l}\text { Diabetic. Abnormal } \\
\text { liver function tests }\end{array}$ & $\begin{array}{l}\text { Excised. Postoperative } \\
\text { biliary fistula. Otherwise } \\
\text { well } 1 \text { year later. Lesion on } \\
\text { ear lobe, also granular cell } \\
\text { myoblastoma }\end{array}$ \\
\hline 14 & Whisnant et al., 1974 & 16 & $\mathbf{M}$ & B & CBD & Obstructive jaundice & $\begin{array}{l}\text { Excised. Well } 1 \text { year later. } \\
\text { Neurofibroma adjacent to } \\
\text { tumour. Lesion on anterior } \\
\text { abdominal wall also } \\
\text { granular cell myoblastoma }\end{array}$ \\
\hline 15 & Reul et al., 1975 & 39 & F & B & Cystic duct & RUQ pain & Excised \\
\hline
\end{tabular}

* B, black; W, White; NS, not stated.

$+\mathrm{CBD}$, common bile duct.

† RUQ, right upper quadrant. 
itself (Fig. 3). The epithelium of the common bile duct was extensively ulcerated probably owing to trauma, but surviving islands were normal with no evidence of hyperplasia. Normal glands were present in the periductal tissue. The lesion was a characteristic granular cell myoblastoma.

\section{Discussion}

Fifteen cases of granular cell myoblastoma of the biliary tree have been reported previously (Table 1). Including the present case, seven were situated in the common bile duct and the remainder (nine) in the cystic duct. When the lesion was in the common bile bile duct the clinical picture was usually of obstructive jaundice, whereas with cystic duct lesions right upper quadrant (RUQ) pain was the usual symptom. Except for the case described by Coggins (1952) and one in Whitmore's series (Whitmore et al., 1969) which was diagnosed incidently at postmortem, all cases were successfully treated surgically. Of the reported cases only one was male, and the age range (excluding Whitmore's case) was $15-45$ years. The race was not stated in five cases; all the remainder except the present case were Negro. This predilection for black females has been found in granular cell myoblastomas at other sites (Vance and Hudson, 1969). Two of the reported cases had granular cell myoblastomas elsewhere and in one of these (Whisnant et al., 1974) there was also a neurofibroma adjacent to the lesion in the common bile duct.

The histogenesis of granular cell myoblastoma is controversial. In his original paper Abrikossof (1926) believed that the lesion was a neoplasm arising from myoblasts or embryonal striated muscle cells. This view was supported by the tissue culture work of Murray (1951). Azzopardi (1956) and others have proposed that the lesion is a metabolic disorder rather than a neoplasm and that the granular cells are histiocytes. Fust and Custer (1949) considered that the lesions were neoplasms arising from nerves. The neurogenic origin was supported by the histiochemical and electron microscopic studies of Fisher and Wechsler (1962), who considered that the lesion arose from Schwann cells but that it was more likely to be histiocytic than neoplastic. They proposed the term 'granular cell Schwannoma', which has not however been widely accepted. Other workers have accepted a Schwann cell origin but conclude that a neoplastic nature is more likely (Sobel et al., 1971).

A number of granular cell myoblastomas of the biliary tree have been described showing a close association with nerve fibres and in the present case granular cells were present around and within nerve bundles. This feature tends to support the theory of origin from Schwann cells.

Granular cell myoblastoma is rare in the extra- hepatic biliary tree but the lesion is readily curable. It should especially be considered in the differential diagnosis of obstructive jaundice or chronic cholecystitis in young black women.

\section{Acknowledgments}

We thank Professor P. J. Scheuer, Dr P. P. Anthony and Dr C. R. Tribe for their help and advice and Mr H. J. O. White for permission to publish this case.

\section{References}

Abrikossoff, A. (1926) Über Myome ausgehend von der quergestreiften Willkürlichen Muskulatur. Virchows Archiv für pathologische Anatomie, 260, 215.

AbT, A.B., Geinberg, E. \& Kaunitz, S. (1971) Granular cell myoblastoma of the extrahepatic biliary tree. Mount Sinai Journal of Medicine New York, 38, 457.

Azzopardi, J.G. (1956) Histogenesis of the granular cell myoblastoma. Journal of Pathology and Bacteriology, 71, 85.

Christensen, A.H. \& IsaK K.G. (1970) Benign tumours and pseudotumours of the gall bladder. Report of 180 cases Archives of Pathology, 90, 423.

Coggins, R.P. (1952) Granular cell myoblastoma of the common bile duct: report of a case with autopsy findings. Archives of Pathology 54, 398.

Duncan, J.T. Jr \& Wilson, H. (1957) Benign tumour of the common bile duct. Annals of Surgery, 145, 271.

Fialho, F. \& Hilarco, J. (1952) Rabdomioma granuloso do cystico. Revista brasileira de medicina, 9, 616.

Fisher, E.R. \& WECHSLER, H. (1962) Granular cell myoblastoma-a misnomer. Cancer, 15, 936.

Fust, J.A. \& CuSTER, R.P. (1949) On the neurogenesis of the so-called granular cell myoblastoma. American Journal of Clinical Pathology, 19, 522.

Goldman, L.I., Lemole, G., Ellis, R. \& Rosemond, G. (1967) Granular cell myoblastoma of the cystic duct. Journal of the American Medical Association, 200, 133.

Li Volsi, V.A., Perzin, K.H. \& BAdder, E.M. (1973) Granular cell tumours of the biliary tract. Archives of Pathology, 95, 13.

Mackay, B., Elliott, G.B. \& MacDougall, J.A. (1968) Granular cell myoblastoma of the cystic duct: report of a case with electron microscope observations. Canadian Journal of Surgery, 11, 44.

MurRay, M.R. (1951) Cultural characteristics of three granular cell myoblastomas. Cancer, 4, 857.

Paskin, D.L., Hull, J.D. \& Cookson, P.J. (1972) Granular cell myoblastomas: a comprehensive review of 15 years experience. American Surgeon, 175, 501.

Reul, G.J., Rubio, P.A. \& Berkman, N.L. (1975) Granular cell myoblastoma of the cystic duct. A case associated with hydrops of the gall bladder. American Journal of Surgery, $129,583$.

Serpe, S.J., Todd, D. \& Barcuh, H. (1960) Cholecystitis due to granular cell myoblastoma of the cystic duct. American Journal of Digestive Diseases, 5, 824.

Sobel, H.J., Marquet, E., Avrin, E. \& Schwartz, R. (1971) Granular cell myoblastoma. American Journal of Pathology, 65, 59.

VANCE, S.F. \& Hudson R.P. (1969) Granular cell myoblastoma. Clinicopathologic study of 42 patients. American Journal of Clinical Pathology, 52, 208.

Whisnant, J.D., BenNett, S.E., HufFMan, S.R., Weiss, D.L., PARKer, J.C. \& Griffin, W.O. (1974) Common bile duct obstruction by granular cell tumor (Schwannoma) American Journal of Digestive Diseases, 19, 471.

Whitmore, J.T., Whitley, J.P. LAVerde, P. \& Cerda, J.J. (1969) Granular cell myoblastoma of the common bile duct. American Journal of Digestive Diseases, 14, 516. 